\title{
Anna Jaroszewska \\ Uniwersytet Warszawski \\ KILKA UWAG NA \\ TEMAT METODOLOGII \\ BADAŃ PROWADZONYCH \\ WŚRÓD OSÓB W WIEKU SENIORALNYM
}

\section{Several remarks on the methodology of research carried out on senior citizens}

\begin{abstract}
The purpose of the article is to draw attention to the specific nature of pedagogical research carried out in research groups represented by people in late adulthood. On the basis of the characteristics of the last stage of a person's development, the author attempts to indicate such research methods and techniques and such an approach to them as will enable the optimization of broadly understood research upon the process of foreign language learning by elderly people.
\end{abstract}

Niniejszy artykuł ma na celu zwrócenie uwagi na specyficzny charakter badań pedagogicznych prowadzonych w grupach badawczych reprezentowanych przez osoby w wieku późnej dorosłości. Jednocześnie nie jest jego celem wdawanie się w spór o to, które $\mathrm{z}$ metod badawczych (ilościowe $v$ s jakościowe) sa „lepsze” bądź „gorsze”. Tym bardziej, że spór ten w ostatnich latach osłabł i zaobserwować można raczej tendencję do umacniania się kompromisu na tym polu (Palka 2006:60-n.; Krüger 2007:185-n.; Łobocki 2007:59). Ów kompromis, poza względnym równouprawnieniem w kręgach naukowych badań ilościowych i badań jakościowych, jawi się m.in. w pluralistycznym podejściu do badań pedagogicznych, które znajduje coraz częstsze zastosowanie w praktyce badawczej. W podejściu tym dominuje przekonanie, że dla zbadania określonego problemu celowe jest przeprowadzanie zarówno badań ilościowych, jak i jakościowych. Wynika to z ich komplementarności. Uogólniając można bowiem przyjąć, że każda z tych strategii (ilościowa/jakościowa) służy do 
osiagnięcia innych celów i ukazuje zupełnie inny obraz badanych procesów nawet wtedy, gdy są to procesy tożsame. Ich kompilacja umożliwia zaś pełniejsze/ głębsze zbadanie określonego problemu (Bauman 2001:267-n.; Łobocki,2006: 16-21; Rubacha 2008: 20-n.). Takie też stanowisko podtrzymane zostało w niniejszych rozważaniach.

Zasadniczym celem prowadzenia badań naukowych jest rozwiązanie jakiegoś problemu. W przypadku podjętych rozważań o problemie badawczym można będzie mówić w gruncie rzeczy wówczas, gdy postawione zostanie pytanie dotyczące szeroko rozumianej edukacji osób w trzecim wieku życia, na które nie udzielono dotychczas wyczerpującej odpowiedzi w dyskursie naukowym (zob. Pilch 2001a:43; Palka 2006:11-n.). To głównie sposób, w jaki problem badawczy (owo pytanie) zostanie sformułowany, a przede wszystkim zakres i rodzaj informacji wymaganych do jego rozwiązania będa warunkowały dobór określonych metod, technik i narzędzi badawczych ${ }^{1}$. W znaczącym stopniu decydowała będzie o tym również specyfika grupy badawczej oraz przygotowanie merytoryczne i postawa prowadzącego badania.

Uczniowie znajdujący się w okresie rozwojowym określanym mianem późnej dorosłości², która może rozpoczynać się już ok. 55-60. roku życia, stanowią współcześnie coraz liczniejsza, a jednocześnie coraz bardziej liczącą się grupę społeczną. Ich aktywność edukacyjna z jednej strony jest konsekwencją postępu cywilizacyjnego, z drugiej zaś ma związek z ogólnoświatowym procesem starzenia się populacji (zob. Komisja Europejska 2005). Tak, jak każdej innej grupie (wiekowej, społecznej, etnicznej itd.), tak i tej można przypisać pewne cechy/właściwości reprezentatywne, które wyróżniają ją spośród innych grup (zob. Straś-Romanowska 2005:263-n.).

Podstawowym wyróżnikiem tej grupy (seniorów), jeśli odnieść się wyłącznie do aspektu edukacji w rozumieniu procesu organizacyjnego, jest charakter relacji i zależności, jakie występuja pomiędzy ,uczniem” a placówką oświatową. Kształcenie seniorów cechuje poszkolność. A zatem musi być ono zawsze dobrowolne. Wyraża się więc w procesach samokształcenia, dokształcania, doskonalenia oraz kształcenia bezinteresownego (Wiatrowski 2003: 904-905). Może przy tym przybierać różne formy organizacyjne. Jedną z takich form jest „kształcenie na odległość”, na przykład poprzez udział w kursach

\footnotetext{
${ }^{1}$ Literatura przedmiotu, a właściwie jej autorzy, różnie odnoszą się do terminologii używanej na gruncie badań pedagogicznych. W tym przypadku interpretacji wymagają takie terminy, jak: metoda, techniki oraz narzedzia badawcze. Zdarza się bowiem, że stosowane są one zamiennie, a to prowadzi niekiedy do nieporozumień. Na gruncie niniejszych rozważań za metodę uznaje się określony, ugruntowany teoretycznie sposób postępowania badawczego, w ramach którego wykorzystywane są techniki - charakterystyczne dla danej metody czynności praktyczne zmierzające do gromadzenia danych badawczych przy użyciu określonych narzedzi (zob. Pilch 2001b: 71 - 72; Łobocki 2007:231).

2 zob. Harwas-Napierała/Trempała 2005.
} 
korespondencyjnych czy też w projektach internetowych, radiowych bądź telewizyjnych. Kształcenie seniorów może być także procesem silnie zindywidualizowanym i stosunkowo hermetycznym. Będzie się wówczas ograniczało do samodzielnego uczenia się przy wykorzystaniu dostępnych źródeł informacji znajdujących się w najbliższym otoczeniu. Szczególną rolę współcześnie zaczynają jednak odgrywać takie formy edukacji ludzi starszych, które opierają się głównie na relacjach międzyludzkich, i w których aktywny udział nauczycieli/ specjalistów jest istotnym czynnikiem warunkującym ostateczny sukces edukacyjny (w szerokim tego słowa znaczeniu). Wymienić tu należy przede wszystkim kursy, warsztaty bądź innego rodzaju zajęcia w klubach seniora, w ramach stowarzyszeń społecznych, w domach kultury czy też pod patronatem Uniwersytetów Otwartych i Uniwersytetów Trzeciego Wieku (zob. Szarota 2004:74-n; Szatur-Jaworska/Błędowski/Dzięgielewska 2006:169-n.). Warto zwrócić również uwagę na coraz bogatszą ofertę stricte komercyjnych kursów i seminariów, w których udział może być w części bądź w całości finansowany np. ze środków samorządów terytorialnych czy też w ramach projektów europejskiego programu Grundtvig (zob. Klimowicz/Dębska 2006; Kolanowska i in., 2007: $34-42)$.

To, czy dana osoba zdecyduje się na uczestnictwo w procesie kształcenia ustawicznego oraz jakiego rodzaju będzie to proces (na odległość z udziałem doradcy, indywidualny, interpersonalny), w dużym stopniu zależało będzie od jej osobowości i życiowej postawy (aktywna vs pasywna). Nie bez znaczenia będą również uwarunkowania zdrowotne, ekonomiczne, społeczne itd. Niemniej za szczególnie istotne uznać należy rzeczywiste potrzeby społeczne takiej osoby. Do potrzeb najbardziej charakterystycznych dla grupy seniorów zaliczyć można:

- potrzebę aktywności vs potrzebę spokoju,

- potrzebę bezpieczeństwa i godnej starości,

- potrzebę towarzystwa,

- potrzebę wymiany intelektualnej,

- potrzebę weryfikacji i zachowania dotychczasowych zdolności psychomotorycznych,

- potrzebę akceptacji przez najbliższych,

- potrzebę pomocy ze strony najbliższych.

W ramach wyróżnionych powyżej „modeli edukacyjnych” seniorzy moga pogłębiać/utrwalać swoją wiedzę oraz rozwijać/utrzymywać określone kompetencje. Wśród nich mogą znaleźć się niewątpliwie wiedza i umiejętności w zakresie porozumiewania się w języku obcym. Mając na względzie kontekst niniejszych rozważań warto zatem wskazać na te cechy, które proces nauczania/uczenia się języków obcych wspierają oraz takie, które mogą go utrudniać. W grupie pierwszej znajdują się:

- silne zmotywowanie do nauki,

- utrzymująca się wysoka zdolność myślenia abstrakcyjnego, 
- zróżnicowane zainteresowania,

- dysponowanie wolnym czasem,

- wewnętrzna potrzeba podnoszenia swoich kwalifikacji i kompetencji,

- chęć utrzymania sprawności intelektualnej, jak również co najmniej dotychczasowego poziomu kompetencji komunikacyjnych w jezzyku obcym,

- posiadanie dużego bagażu doświadczeń, także tych mających związek z wielokulturowością i wielojęzycznością,

- (najczęściej) posiadanie doświadczenia w uczeniu się języka obcego, które ma istotne znaczenie w przypadku systematycznego uczenia się,

- posiadanie podstawowej wiedzy o języku ojczystym pozwalające na wprowadzenie pojęć dotyczących gramatyki języka obcego, choć nie jest to reguła,

- względna niezależność decyzyjna i ekonomiczna pozwalająca na uczestniczenie w różnych formach kształcenia,

- ciekawość otaczającego świata i chęć podróżowania,

- możliwość nawiązania relacji partnerskiej pomiędzy uczniem i nauczycielem,

- potrzeba nawiązywania kontaktów.

W zakres kategorii drugiej można włączyć natomiast:

- duże zróżnicowanie kompetencyjne w zakresie znajomości języka obcego, wymagające odpowiedniego podziału na grupy zaawansowania,

- silnie zakorzenione stereotypy i uprzedzenia względem inności kulturowej, jeśli występują,

- chęć decydowania o sobie i trudności w podporządkowaniu się nauczycielowi,

- złe samopoczucie w grupie uczniów młodszych ${ }^{3}$,

- złe samopoczucie, gdy nauczyciel jest osobą dużo młodszą,

- możliwe braki w wykształceniu ogólnym dotyczące np. podstawowych pojęć gramatycznych, co może mieć związek z procesem zapominania,

- utrwalone negatywne wzorce zachowań, w tym związane z procesem uczenia się,

\footnotetext{
${ }^{3}$ Nawet w tzw. Kursach 50+ może występować duża różnica wieku pomiędzy uczniami uczącymi się w jednej grupie. Różnica pomiędzy uczniem pięćdziesięcioletnim a osiemdziesięciopięcioletnim wynosi aż 35 lat. Uczniowie ci reprezentują więc najczęściej różne pokolenia, co niekiedy staje się przyczyną nieporozumień czy właśnie złego samopoczucia. Problematyczne w tym przypadku może okazać się zatem nieuwzględnianie tej różnicy w ofercie Uniwersytetów Otwartych bądź innych, typowo komercyjnych kursów, gdzie dopuszcza się nauczanie w jednej grupie uczniów osób w wieku lat dwudziestu z osobami w podeszłym wieku. Nie oznacza to jednak, że nie ma osób starszych uczestniczących z przyjemnością w kursach językowych, w których przeważającą większość stanowią uczniowie młodzi.
} 
- złe doświadczenia dotyczące uczenia się języka obcego bądź w ogóle brak doświadczeń w tym zakresie,

- możliwe kryzysy związane z zaniżoną samooceną uaktywniającą się podczas obserwacji innych uczących się,

- nieprzychylność środowiska rodzinnego,

- brak środków na finansowanie nauki języka obcego,

- złe nawyki językowe,

- zmniejszona plastyczność narządów mowy,

- obniżone zdolności percepcyjne związane z osłabieniem wrażliwości wzrokowej i słuchowej, jak również ogólnym obniżeniem sprawności psychomotorycznych,

- nie nadążanie za tempem prowadzonych zajęć (jeśli skierowane są one głównie do osób młodszych),

- przywiązanie do klasycznych metod nauczania, które współcześnie wykorzystywane są w mniejszym stopniu,

- skłonność do szybkiego męczenia się,

- zmniejszająca się zdolność koncentracji uwagi,

- różnice światopoglądowe - tzw. konflikt pokoleń,

- możliwe przerwy w nauce wynikające z coraz częstszych stanów chorobowych bądź obowiązków rodzinnych.

Z perspektywy prowadzonych badań, które zasięgiem obejmują proces kształcenia dorosłych w trzecim wieku życia, istotne wydają się także zmiany w zakresie wszelkich procesów o charakterze poznawczym. Przede wszystkim należy odnotować fakt, że wraz z wiekiem (dot. okresu późnej dorosłości) ich rozwój stopniowo wyhamowuje. Choć proces ten jest różny dla każdego człowieka, to jednak prowadząc badania nad nauczaniem/uczeniem się seniorów trudno byłoby bagatelizować nasilającą się u nich progresję czynników o charakterze uwsteczniającym. Niemniej należy pamiętać o tym, że ważną rolę w tym kontekście odgrywa mechanizm adaptacji do starości, jaki wykorzystywany jest przez daną jednostkę. Nie bez znaczenia jest również dotychczasowy sposób egzystencji. O charakterze procesów poznawczych decyduje bowiem m.in. to, czy osoba starsza preferuje strategię życiowej aktywności, opierającą się na podejściu konstruktywnym, czy też będzie charakteryzowała ją pasywność i skłonność do wycofywania się z życia społecznego. Dlatego też zmiany w procesach poznawczych seniorów mogą być bardzo różne, a przy tym mogą następować w różnym czasie. Do zmian najpowszechniejszych zaliczyć można jednak:

- postępujące osłabienie wrażliwości zmysłowej, w tym osłabienie selektywności uwagi, jak i zdolności do jej długotrwałej koncentracji,

- wydłużenie czasu reakcji na bodźce wzrokowe i słuchowe,

- wydłużenie czasu wykonania czynności,

- ogólne obniżenie sprawności psychomotorycznej,

- obniżenie zdolności zapamiętywania zwłaszcza w odniesieniu do pamięci mechanicznej i bezpośredniej, 
- silne uzależnienie zdolności zapamiętywania od czasu prezentacji materiału oraz jego rodzaju,

- regresywne zmiany w zakresie poziomu inteligencji,

- obniżenie ogólnej sprawności myślenia formalno-logicznego,

- (często) nasilenie chorób wieku podeszłego (tzw. mnoga patologia),

- utrzymującą się, a nawet rozwijającą się zdolność myślenia relatywistycznego,

- osiągnięcie stanu mądrości przejawiającej się w zdolności do abstrahowania od kontekstu życia (tzw. mądrość transcendentna),

- polepszenie warunków do rozwoju duchowego.

Okres późnej dorosłości niewątpliwie wieńczy też całość wcześniejszych zmian rozwojowych, które zachodziły w ciagu całego życia człowieka. Nie jest to jednak czas zastoju, zwłaszcza na gruncie funkcjonowania społecznego. Przeciwnie. Także i dla tego okresu wyróżnić można przemiany charakterystyczne, a więc właściwe przede wszystkim seniorom. Ich znajomość i rozpoznanie również będzie miało znaczenie dla ewentualnych decyzji badacza w zakresie doboru metod, technik i narzędzi badawczych. Wśród zmian takich mogą wystąpić np.:

- (najczęściej) zakończenie aktywności/rozwoju zawodowego,

- zmiana form aktywności z chwila zakończenia kariery zawodowej i związane z tym próby zagospodarowania czasu wolnego,

- zmiany ról społecznych z pracownika na emeryta, przy czym w pierwszej fazie tego okresu nie jest to reguła,

- podjęcie nowych ról społecznych związanych z dorastaniem dzieci np. roli babci/dziadka,

- stopniowy powrót do uzależniania się od pomocy dzieci lub innych osób,

- (często) strata związana ze śmiercią małżonka, jako przełomowy moment w kontekście funkcjonowania społecznego,

- (zazwyczaj) zrealizowanie większości z wyznaczonych w młodości celów życiowych lub pogodzenie się z brakiem możliwości ich realizacji,

- zmiana charakteru czynników stresogennych, na jakie narażony jest człowiek tj. nasilenie zdarzeń krytycznych takich, jak: utrata zdrowia, kondycji i atrakcyjności fizycznej, utrata poczucia przydatności, utrata osób najbliższych, utrata dotychczasowego statusu społecznego/zawodowego/materialnego itp..

Należy podkreślić, że osobowość nie ulega znaczącym przeobrażeniom w okresie późnej dorosłości. Pozostaje ona względnie niezmieniona zwłaszcza w zakresie takich cech, jak: ekstrawersja, neurotyzm, otwartość na doświadczenie, sztywność zasad postępowania czy konfliktowość. Niemniej wyróżnić można w niej takie kategorie/cechy/procesy, które w pewnym zakresie świadczą o zmianach, jakie nastapiły bądź realizują się w jej obrębie. Są to:

- świadomość szeroko rozumianych strat wynikających z procesu starzenia się, która w pierwszej fazie prowadzi do negatywnych emocji 
a niekiedy stanów depresyjnych (występuje tzw. kryzys przełomu dorosłość-starość),

- przewartościowanie celów życiowych objawiające się niekiedy zmianą stylu życia czy filozofii życiowej,

- osiagnięcie integracji psychicznej, co równoznaczne jest z odkryciem sensu życia i przekonaniem o wartości własnej drogi życiowej,

- wzmagające się postawy bierności i uzależnienia od otoczenia (nie jest to reguła),

- osłabianie pewności siebie,

- lęk przed osamotnieniem bądź samotnością, które moga prowadzić do wzmożonej agresywności wobec otoczenia,

- występuje zdolność do autentycznej ekspresji emocjonalnej,

- skłonność do porównań społecznych,

- stopniowe obniżanie potencjału energii życiowej oraz osłabienie biologicznych popędów, co prowadzi do refleksji i sprzyja kontemplacji,

- nasilenie stanów lękowych związanych ze zbliżającą się śmiercia.

Tak, jak w przypadku innych grup wiekowych, tak i wśród seniorów nawet w obrębie jednej grupy badawczej może wystąpić silne zróżnicowanie. Może ono dotyczyć zarówno osobowości, jak i procesów rozwojowych/regresywnych. Zróżnicowanie takie może być przy tym uwarunkowane nie tylko predyspozycjami wrodzonymi, ale przede wszystkim dotychczasowym trybem życia. O szeroko rozumianych predyspozycjach do uczestniczenia w badaniu pedagogicznym będą więc przesądzały m.in.: cechy osobowości i związana z tym postawa życiowa, poziom i kierunek wykształcenia, aktywność zawodowa i pozazawodowa, status społeczny, status ekonomiczny, doświadczenia życiowe, środowisko rodzinne, stopień samorealizacji itd.

Odpowiedź na pytanie: Kiedy odwotywać się do ilościowej koncepcji badan, a kiedy do koncepcji jakościowej? wynika niejako z definicji, w ramach których opisano każdą z tych metodologii. Badania ilościowe, w najszerszym znaczeniu, polegają na ilościowym, a przy tym obiektywnym opisie i analizie faktów, zjawisk oraz procesów w odniesieniu do ogłoszonych już teorii bądź postawionych w oparciu o nie tez lub hipotez badawczych. Opierają się na dedukcyjnym sposobie wnioskowania, a ich zasadniczym celem jest ukazanie związków przyczynowo-skutkowych pomiędzy określonymi zmiennymi (zob. Palka 2006:48-49; Krüger 2007:174; Łobocki 2007:59-61). Badania jakościowe odżegnują się natomiast od rozbudowanych analiz liczbowych, zwłaszcza stricte statystycznych. Zmierzają do ukazania określonego środowiska społecznego i jakościowego opisu właściwych temu środowisku faktów, zjawisk czy zachodzących w nim procesów (np. kształcenia) przede wszystkim poprzez jednostkową analizę działania osób uczestniczących w tych procesach lub będących świadkami owych faktów bądź zjawisk. Analiza ta prowadzona jest głównie z perspektywy osób badanych, a więc ukazuje ich punkt widzenia, myśli, opinie, odczucia, motywy, procesy decyzyjne itp. Jednocześnie 
uwzględnia ona subiektywną ocenę badacza-obserwatora, w niektórych przypadkach także współuczestnika tych procesów. Badania te opierają się na indukcyjnym sposobie wnioskowania, a ich zasadniczym celem jest zrozumienie badanych zjawisk i dokonanie ich interpretacji (Palka 2006:54 -55; Krüger 2007:156; Lobocki 2007:92-93).

Biorąc powyższe pod uwagę nie powinno budzić wątpliwości twierdzenie, że nie wszystkie dane badawcze są mierzalne, podobnie jak i nie każda informacja musi/może być przedstawiona za pomocą opisów jakościowych. Czasami, aby uzyskać pełny obraz badanego zjawiska/problemu należy zbadać jego różne aspekty. Dlatego też, o ile to możliwe i uzasadnione, podejmując badania nad procesem kształcenia np. seniorów warto odwołać się do przywołanej na wstępie eklektycznej koncepcji prowadzenia badań, polegającej na kompilacji czynnika ilościowego z czynnikiem jakościowym w jednym modelu badawczym (zob. Palka 2006:64-n.). W pewnym zakresie pozwala ona bowiem zabezpieczyć się przed zagrożeniami, a przede wszystkim przed ograniczeniami wynikającymi z zastosowania jednej metody gromadzenia i analizy danych badawczych.

Niezależnie jednak od metodologii, która zostanie zastosowana w badaniach prowadzonych wśród osób w wieku senioralnym, należy mieć świadomość, że powodzenie badań w dużym stopniu zależało będzie od technik oraz narzędzi badawczych wykorzystanych w ramach tej metodologii ${ }^{4}$. Przede wszystkim od ich dostosowania do możliwości psychofizycznych, postaw, ale także i potrzeb osób badanych. Pomimo różnic w klasyfikacji oraz nazewnictwie poszczególnych metod a częściowo także technik i narzędzi badawczych, jakie zauważyć można u różnych autorów specjalizujących się w problematyce badań pedagogicznych ${ }^{5}$, opis ich przeznaczenia, jak również metodyka postępowania badawczego przy ich wykorzystaniu została w literaturze przedmiotu opisana bardzo szczegółowo. Nie ma więc sensu powielanie tych informacji w tak zwartej publikacji. Warto skoncentrować się natomiast na postawie badacza, do zadań którego należy nie tylko przeprowadzenie badań, lecz także ich zaplanowanie i przygotowanie. Już na pierwszym etapie (planowania) badań powinien on dokonać wstępnego rozpoznania grupy badawczej m.in. w zakresie wymienionych tu właściwości (cechy, możliwości, postawy, wiedza, doświadczenia, potrzeby itd.), na co zwracano już uwagę. W oparciu o te informacje może on ocenić, czy podmiot badań

\footnotetext{
${ }^{4}$ Upraszczając można przyjąć (za: Palka 2006:48-60), że metodami (oraz stosowanymi w ich zakresie technikami i narzędziami) badań ilościowych są: obserwacja, skalowanie, wywiad skategoryzowany, ankieta, socjometria, test, analiza dokumentów oraz eksperyment. Ich odpowiednikiem w zakresie metodologii badań jakościowych są natomiast: obserwacja uczestnicząca, wywiad swobodny - narracyjny, introspekcyjny, otwarty, analiza treści dokumentów osobistych, metoda biograficzna oraz badanie w działaniu.

${ }^{5}$ zob. np.: Pilch/Bauman 2001; Lobocki 2006; Palka,2006; Maszke 2008 i in.
} 
jest na tyle otwarty i samodzielny, że będzie skłonny np. wypełnić arkusz testu bądź ankietę zawierającą m.in. zestaw pytań otwartych czy też warto raczej zastosować wobec niego obserwację lub podjąć próbę przeprowadzenia wywiadu. Jeśli bowiem okaże się, że osoba badana zalicza się do grona osób nieśmiałych, skrytych, zamkniętych w sobie, niecierpliwych, nie w pełni samodzielnych lub też wykazujących oznaki regresywnych zmian w zakresie funkcjonowania psychoruchowego (utrudniające proces badawczy), zasadne będzie możliwie jak najaktywniejsze uczestnictwo w procesie gromadzenia danych badawczych. Optymalnym rozwiązaniem jest wówczas osobisty kontakt z osobą badana. Z jednej strony kontakt taki zapewnia dostęp do szeregu informacji, które moga zostać bezpowrotnie zatracone w badaniu o charakterze pośrednim (np. reakcja na prezentowaną treść, uwagi krytyczne co do sposobu postawienia pytania, nowe watti badawcze, podjęcie których postuluje podmiot badań itp.). Z drugiej zaś strony osobisty kontakt pomiędzy badającym i osobą badana pozwala na nawiązanie głębszej relacji, na zatarcie anonimowości w badaniu, zwłaszcza anonimowości badacza, która może niekiedy przyczyniać się do zobojętnienia i braku zaangażowania ze strony uczestniczących w badaniu osób, w tym przypadku seniorów. Co więcej, taka dwukierunkowa relacja stwarza możliwość nie tylko pobudzenia/ zaktywizowania podmiotu badań, lecz także zapewnia mu komfort dostępu do szczegółowej wiedzy na temat celu badania czy sposobów analizy zgromadzonych w jego toku danych badawczych, a więc m.in. informacji dostarczonych przez niego. To zaś przekłada się na poczucie bezpieczeństwa oraz świadomość, że jeśli tylko okaże się to niezbędne, to osoba badana zawsze może liczyć na pomoc (co najmniej w zakresie dotyczącym badań, w których uczestniczy). Choć kwestie powyższe okazują się szczególnie istotne na etapie badań jakościowych, to nie pozostaja również bez wpływu na jakość przeprowadzonych badań o charakterze ilościowym. Należy jednak pamiętać, że w przypadku podejścia ilościowego podstawowym, w pewnym zakresie odgórnym, celem badań jest przedstawienie prawdy obiektywnej na określony temat. Często można zatem napotkać na postulaty o nieangażowanie się (w rozumieniu osobistego poznania podmiotu badań) badacza w proces gromadzenia danych badawczych, jeśli mogłoby to później utrudnić obiektywną ocenę tych danych.

W sytuacji, w której brak jest możliwości nawiązania bezpośredniego kontaktu z osobami badanymi (np. uniemożliwia to odległość, mnogość grupy badawczej bądź jest to po prostu zamierzone), wszelkie narzędzia badawcze (np. ankiety, kwestionariusze, testy itd.) powinny zostać opatrzone stosownymi opisami, wyjaśnieniami, wskazówkami czy instrukcjami sformułowanymi w taki sposób, aby starsza osoba przystępując do badania nie miała żadnych wątpliwości co do tego, czego się od niej oczekuje. Pomocna okazuje się w tym przypadku postulowana charakterystyka grupy badawczej. Istotny jest przy tym nie tylko sam język wypowiedzi (musi być po prostu zrozumiały), 
lecz także forma graficzna, w jakiej zostanie przedstawiony. Na problem ten należy zwrócić uwagę na etapie konstruowania wszystkich elementów składających się na narzędzie badawcze. Poszczególne pytania niech będą zatem wyraźnie oznaczone i sporządzone większą czcionką (np. 14-16 pkt.). Dotyczy to także treści zadań czy tekstów wewnętrznych badania, z którymi seniorzy mają się zapoznać, i na podstawie których mają wykonać określone czynności. Nie powinny być one zbyt długie. Warto także stosować konstrukcję zdania prostego, aniżeli wielokrotnie złożonego. Jeśli w badaniu zadaniem seniorów ma być wypełnienie ankiety i udzielenie odpowiedzi na pytania zamknięte uwzględniające element skalowania/wartościowania, niech budowa takiego pytania będzie prosta. Możliwości wyboru niech będą jasno określone, zaś poszczególne odpowiedzi wyraźnie od siebie oddzielone. Jeżeli natomiast w zamierzeniu badacza znajdzie się uzyskanie pisemnej odpowiedzi na pytania otwarte, pozostawiając miejsce na odpowiedź niech uwzględni on większe pismo osób starszych. Często naznaczone jest ono już drżeniem (tremor), niespójnym charakterem, niekiedy zaś okazuje się w ogóle nieczytelne. Zdarza się, że bez okularów uczestnik badania nie będzie w stanie pisać ani też czytać, dlatego należy zwrócić jego uwagę na to, aby nie zapomniał ich przystępując do badań. Sama ankieta (lub inna technika/narzędzie gromadzenia danych) niech będzie zaś możliwie krótka i przejrzysta. Materiał wizualny wykorzystywany $\mathrm{w}$ badaniach powinien być $\mathrm{z}$ kolei odpowiednio duży i skontrastowany pod względem doboru barw. Materiał do odsłuchiwania powinien mieć odpowiednie natężenie głosu, a wypowiedzi w nim zawarte musi cechować wyraźna artykulacja, wolniejsze tempo oraz brak szumów. Za szczególnie ważną uznać należy również dbałość o jakość merytoryczną treści stanowiących przedmiot badania, jak i ich zakres tematyczny. Należy bowiem dopuścić okoliczności, w których osoba starsza (podmiot badania) będzie posiadała szeroką, interdyscyplinarną wiedzę oraz bogate doświadczenie życiowe w zakresie określonego tematu badawczego. Ponadto w zakresie badań powinna zostać zachowana „granica bezpieczeństwa”, która będzie uwzględniała większą wrażliwość psychiczną starszego pokolenia na treści, zachowania czy poglądy, które współcześnie nie budzą kontrowersji czy sprzeciwu ludzi młodych. W końcu warto wspomnieć o zasadzie stopniowania trudności zadań badawczych. Zaleca się przy tym, aby np. pytania o aspekty szczególnie ważne dla badacza zadawane były możliwie wcześnie. Jest to o tyle trudne, że całość badania powinna cechować spójność oraz równomierny rozkład treści. Niemniej, postulat powyższy ma związek z tym, że wraz z czasem poświęconym na badanie oraz wysiłkiem włożonym w wypełnianie kolejnych zadań (jeśli wymagana jest aktywność podmiotu badań), wzrasta skłonność seniorów do przemęczenia nie tylko fizycznego, ale i intelektualnego. Co więcej, upływający czas przesądza również o ich wzrastającym zniecierpliwieniu. Jeśli więc na wstępie skonfrontowani zostana $z$ materiałem nieciekawym lub trudnym w odbiorze może się 
okazać, że nie podejmą oni wysiłku i po krótkim czasie zrezygnują z udziału w badaniu, bądź co gorsze, poszczególne zadania zrealizują bez właściwego zaangażowania (np. odpowiedzi niezgodne z przekonaniami, niewypełnione pola pytań otwartych, przypadkowe odpowiedzi w zakresie pytań o charakterze wartościującym, odpowiedzi w teście zaznaczane na „chybił/trafił” itd.). To zaś znacząco może wpłynąć na wiarygodność zgromadzonych informacji badawczych. W pewnym stopniu może więc przyczynić się do niepowodzenia w zakresie prowadzonych badań.

\section{BIBLIOGRAFIA}

Bauman, T. 2001. „Strategie jakościowe w badaniach pedagogicznych”, (w) Pilch, T., Bauman, T. 2001. Zasady badań pedagogicznych. Strategie ilościowe i jakościowe. Warszawa: Wydawnictwo Akademickie „Żak”, s. 267-362. Harwas-Napierała, B., Trempała, J. (red.) 2005. Psychologia rozwoju cztowieka. Charakterystykea okresón życia cźtowieka. Warszawa: Wydawnictwo $\mathrm{Na}$ ukowe PWN.

Klimowicz, G., Dębska, A. 2006. Program Socrates w Polsce. Efekety wspótpracy 1998-2006. Warszawa: Fundacja Rozwoju Systemu Edukacji.

Zielona Ksiega 2005. Wobec żmian demograficznych: nowa solidarność międz y pokoleniami. Bruksela: Komisja Europejska.

Kolanowska, E. i in. 2007. Program Socrates Grundtvig w Polsce w latach: 2000-2005. Akcje scentralizowane. Warszawa: Fundacja Rozwoju Systemu Edukacji.

Krüger, H.-H. 2007. Metody badań w pedagogice. Gdańsk: Gdańskie Wydawnictwo Psychologiczne.

Lobocki, M. 2006. Metody i techniki badań pedagogicznych. Kraków: Oficyna Wydawnicza „Impuls”.

Łobocki, M. 2007. Wprowadzenie do metodologii badań pedagogicznych. Kraków: Oficyna Wydawnicza „Impuls”.

Maszke, A.W. 2008. Metody i techniki badań pedagogicznych. Rzeszów: Wydawnictwo Uniwersytetu Rzeszowskiego.

Palka, S. 2006. Metodologia. Badania. Praktyka pedagogiczna. Gdańsk: Gdańskie Wydawnictwo Psychologiczne.

Pilch, T. 2001a. „Filozoficzne i pragmatyczne pojęcia badań empirycznych”, (w) Pilch, T., Bauman, T. 2001. Zasady badań pedagogicznych. Strategie ilościowe i jakościowe. Warszawa: Wydawnictwo Akademickie „Żak”, s. 15-69.

Pilch, T. 2001b. „Strategie ilościowe w badaniach pedagogicznych”, (w) Pilch, T., Bauman, T. 2001. Zasady badań pedagogicznych. Strategie ilościowe i jakościowe. Warszawa: Wydawnictwo Akademickie „Żak”, s. 70-266.

Rubacha, K. 2008. Metodologia badań nad edukacja. Warszawa: Wydawnictwa Akademickie i Profesjonalne.

Straś-Romanowska, M. 2005. „Późna dorosłość. Wiek starzenia się”, (w) Harwas-Napierała, B., Trempała, J. (red.). 2005. Psychologia rozwoju 
çztowieka. Charakterystyka okresón życia cz̧towieka. Warszawa: Wydawnictwo Naukowe PWN, s. 263-292.

Szarota, Z. 2004. Gerontologia spotecz̧na i ośniatowa. Zarys problematyki. Kraków: Wydawnictwo Naukowe Akademii Pedagogicznej.

Szatur-Jaworska, B., Błędowski, P., Dzięgielewska, M. 2006. Podstany gerontologii spotecznej. Warszawa: Oficyna Wydawnicza ASPRA-JR.

Wiatrowski, Z. 2003. „Kształcenie ustawiczne dorosłych”, (w) Pilch, T. (red.). 2003. Encyklopedia Pedagogiczna XXI wieku. Tom II: G-亡, Warszawa: Wydawnictwo Akademickie „Żak”, s. 903-910. 